\title{
FESTA E IDENTIDADE NUNHA PARROQUIA DE NEMANCOS
}

\author{
por \\ MANUEL VILAR ÁLVAREZ
}

Coucieiro é unha parroquia «interior» do concello de Muxía e tiña 502 fregueses no 1986 (fronte aos 6.411 habitantes que tiña o concello), espallados en 15 núcleos ou aldeas (Torres Luna; 1989). A principal fonte de vida das súas xentes foi o traballo no campo xunto coa industria de transformación da madeira, na parroquia hai dous serradoiros que empregan a máis de 40 obreiros e moitos deles son doutros lugares de fóra. Hoxe son poucos os que viven da agricultura ou da gandería, pero en case todas as casas podemos atopar aínda dúas ou tres vacas; séguese a plantar as patacas precisas para o autoconsumo e algún millo. As escenas da malla case desapareceron e foron substituídas polas da herba, aínda que moitas veces só o fagan «pa sacala dos herbales». A emigración temporal a Suíza, a construcción e os subsidios dos vellos son outras fontes de ingresos e de subsistencia.

Coucieiro é unha das 14 parroquias de que consta o concello de Muxía, segundo as estatísticas oficiais. Pero ningún muxián será capaz de contar as 14 parroquias, contará 12 ou contará incluso menos, xa que para eles Nemiña (a onde ía Pondal estudiar latín) e Caberta cos seus 149 e 173 fregueses, as súas pequenas igrexas románicas, as súas festas e os seus cemiterios, non teñen tal categoría polo que reciben o nome de anexos. Caberta é anexo de Coucieiro, Nemiña é o de Touriñán, aínda que esta última sexa menor en extensión e en fregueses. Hai outras parroquias muxiás que non superan o número de fregueses de calquera destes dous anexos, pero teñen moi clara a súa condición e categoría de parro-

"CUADERNOS DE ESTUdiOS GALLEGOS", Tomo XLII, Fascículo 107, Santiago 1995. 
quia. Son parroquias Bardullas, Buiturón, Leis e a $\mathrm{O}$ (pronuncian On). Moitas veces os veciños da parroquial omitirán o nome da secundaria, do anexo, nunha conversa nun claro intento de manter esta categorización, así dirán: «murríu un no Anexo» ou «ese casou no Anexo», en vez de dicir «murríu un no Anexo» ou «ese casou no Anexo».

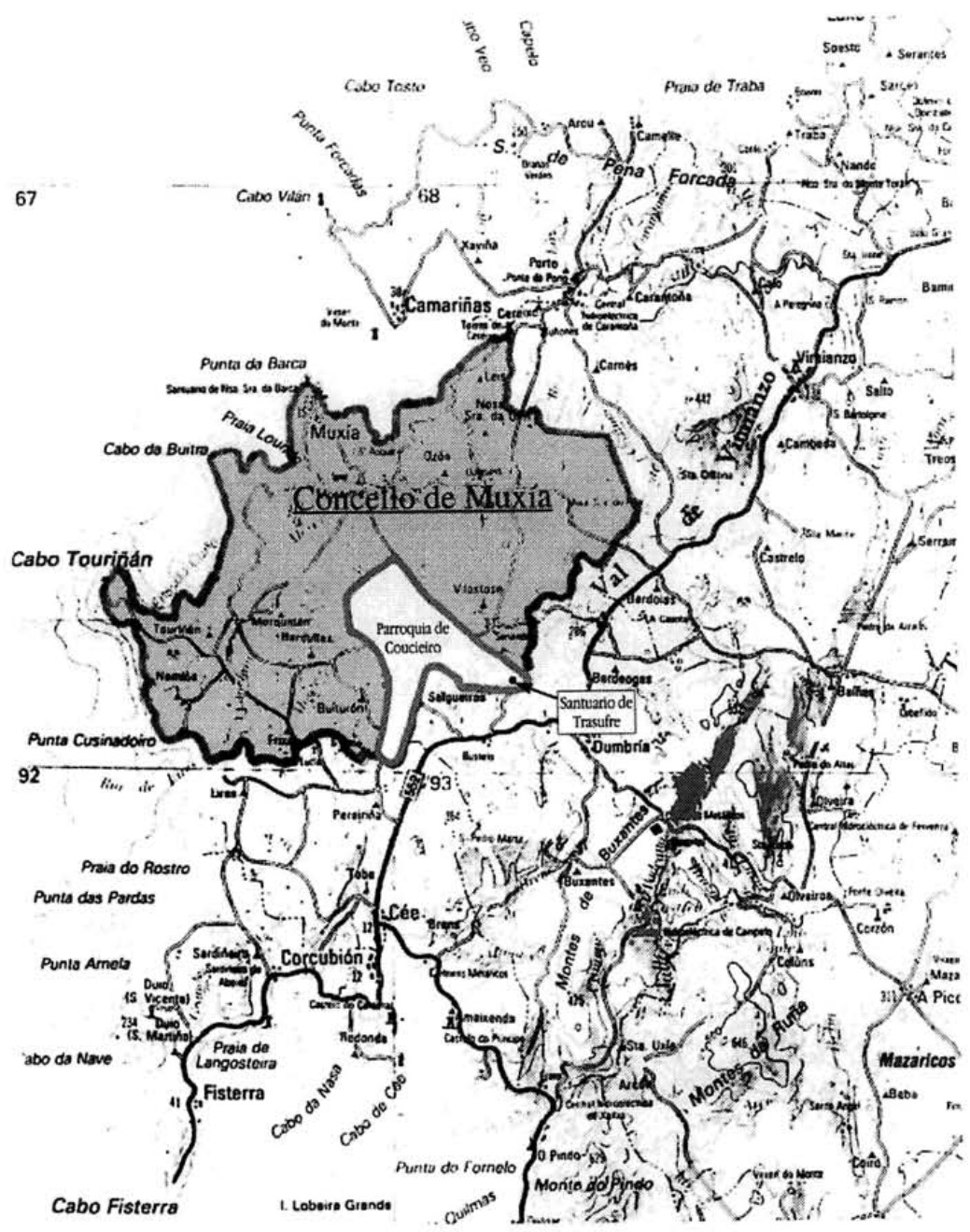

Mapa 1. Situación da zona.

"CUADERNOS DE ESTUdIOS GALLEGOS", Tomo XLII, Fascículo 107, Santiago 1995. 
Na parroquia de Coucieiro celébranse hoxe as seguintes festas: a do patrón S. Pedro, que case pasa desapercibida e poderiámola chamar unha festa de pote (García e outros; 1991); o Socorro, que é a festa parroquial por excelencia, Sto. Antonio ou tamén «po outro dia do Socorro», Sta. Mariña, o 18 de xullo e Aránzazu ou o Espiño, pero chamada popularmente $A$ Santiña que se celebra o 21 de setembro coa Sta. Margarita ao día seguinte. Antes celebrábase, tamén, S. Miguel, o Rosario e as Flores. Caberta, o anexo da parroquia de Coucieiro, tamén ten a súa festa patronal: o San Fins, que celebran o primeiro de agosto. Ao día seguinte celebran o Santo Antonio, tamén celebran o Socorro e o Rosario, aquel en maio e este o primeiro domingo de outubro.

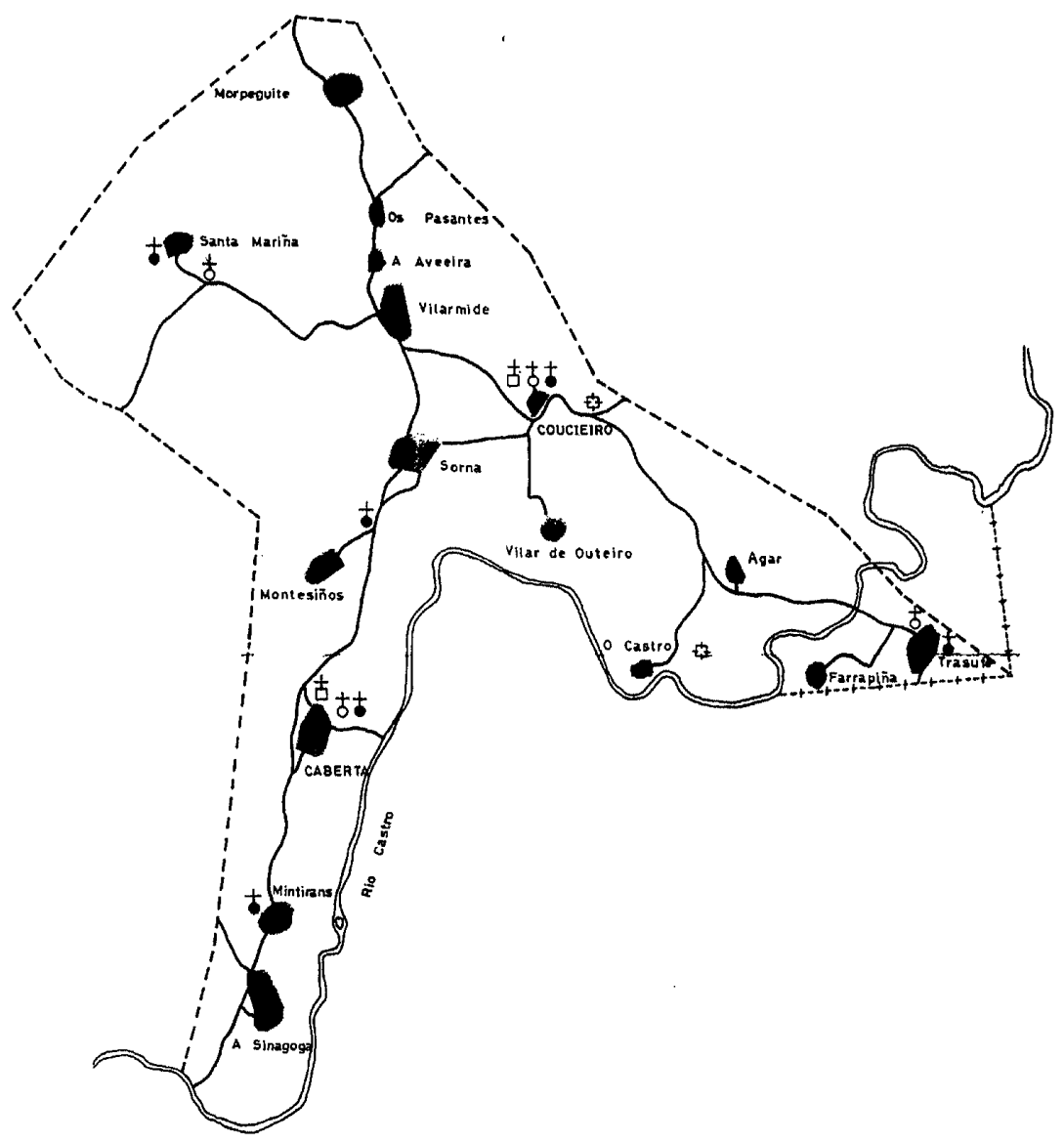

Mapa 2. A parroquia de Coucieiro e o seu «anexo» Caberta.

"CUADERNOS DE ESTUdiOs GALlEGOS", Tomo XLII, Fascículo 107, Santiago 1995. 
Cando aquí falo de festas falo daquelas que teñen un compoñente relixioso e outro lúdico ou festivo propiamente dito. Omito outras que tamén se celebran, aínda que malamente, como o entroido ou o Corpus. A participación na festa non implica ou non significa principalmente unha participación nos actos relixiosos, máis ben debe entenderse como participación nun acto de identidade e recreación colectiva.

\section{A FESTA DO PATRÓN}

A festa do patrón é a do San Pedro, pero desde hai uns anos para aquí a penas ten xa incidencia na vida parroquial. Moita xente que traballa fóra nun traballo asalariado, ou vive nas vilas e cidades, non se poden desprazar para celebrala. Hoxe tan só se celebra unha misa moi pouco concorrida e nalgunhas casas faise un xantar algo diferente ao dos outros días. Antes si era unha festa como outras, non se traballaba, íase a misa, sacábase o santo na procesión, xuntábase a familia e había comida da festa. Xa moi pouca xente lembra que nesta festa houbese baile, si o había pola noite en salóns privados pero non o había no campo parroquial.

A súa estrela apagouse en beneficio da máis brillante do Socorro, unha festa máis recente e que nace nos anos vinte deste século, e que moi axiña se converteu na festa principal da parroquia, de toda a parroquia. Os veciños de Caberta tamén participan da festa do Socorro, mais non fan, nin facían, o mesmo coa do San Pedro. Esta non era a súa festa. O San Pedro tamén tiña o seu segundo día que era o día adicado ao Sagrado Corazón de Xesús, unha devoción traída de Bos Aires por uns emigrantes do lugar de Sorna.

Pero a festa grande, a que representa a toda a parroquia, para a que se espera para estrear a roupa nova, é a do Socorro que se celebra o primeiro domingo do mes de xullo e, como festa, non difire moito doutras festas parroquiais. Pola mañá hai unha misa primeira á que van os que teñen loito ou as persoas que non poden ir á misa maior, é dicir, as mulleres que logo teñen que atender os labores domésticos. Sobre a unha e media celébrase a misa solemne, tamén chamada cantada, de capotes ou maior, con máis pompa. No momento da consagración a orquestra toca o himno, que en moi raras ocasións é o galego. Logo hai procesión na que saen a Virxe do Socorro, levada por homes da parroquia, e mais Sto. Antonio, levado por mulleres. "O Socorro era das ofretas», en referencia a que os que o levaban tíñanse ofrecido á Virxe. Fan un percorrido polo campo da festa até o cruceiro (uns cen metros) para dar volta, entrar no adro e bordeando o

"CUADERNOS DE ESTUdiOS GALlEGoS", Tomo XLII, Fascículo 107, Santiago 1995. 
templo volver a entrar nel. Os homes que ían na procesión, agás os que portan a imaxe, xa non volverán entrar na igrexa e, unha vez que as imaxes atravesen a porta, eles, empezando unha conversa, irán cara ao espacio lúdico.

A procesión vai presidida pola cruz parroquial de prata, que consta que xa estaba na parroquia no ano 1733, séguea o guión «que é un maiordomo da festa quen o leva e vai abrindo paso na procesión», e despois o estandarte, «que é propio da cofradia, si é dun santo, un santo, e si é dunha santa, unha santa». Así mo contou un informante, pero a realidade é que o estandarte o leva case sempre unha muller e sae sempre o mesmo e o guión xa hai uns anos que non sae. Despois vai a imaxe da Virxe, tras ela os curas, a orquestra e os fregueses. Nun primeiro plano van as mulleres e logo os homes, que moitos deles nin tan sequera chegaron a entrar na igrexa. Os nenos van diante da imaxe e se algún fixo a primeira comunón levará as cintas que colgan do estandarte.

Aparentemente a procesión non ten unha orde definida e estructurada; van todos, máis ou menos, xuntos, como o fan na vida diaria. A procesión é unha imaxe da aparente unidade social dos vecinos «e da forma en que esta contempla a súa propia estratificación» (Homobono; 1989, 475).

Pero o máis significativo desta festa pode ser unha danza de arcos que se baila durante a procesión. A danza foi copiada doutra existente no concello limítrofe de Camariñas por iniciativa dun mozo da parroquia, Lorenzo do Satre. Este home foi o que tamén implantou o culto á Virxe do Socorro. Contan que

foi á gherra a Marruecos e estivo de asistente dun capitán e ali foi onde culliu devosión a esta Virghen. El non estaba mal pero debiu de ver algho malo. Era o único carpinteiro de verdá que habia por aqui: fasia santos, fasia muebles. Cando vén da mili organisou unha festa, fixo unha prosisión cun cuadro, nin imaghen habia, logho trouxo a dansa de Camariñas e despois ven varias veses o maestro a ensaiar aquí.

Segundo este informante, emparentado co Lorenzo, foron os de Camariñas os que viñeron coa danza ata Coucieiro para, nos anos seguintes, despra-zarse só o mestre a ensaiar aos mozos de Coucieiro. Despois xa foron mozos da parroquia os que facían de maestro, de encargado de dirixir os danzantes e de levar con maestría a danza.

"CUADERnOS DE ESTUdIOS GALlEGOS", Tomo XLII, Fasciculo 107, Santiago 1995. 
Esta danza foi representada até os anos 50-60, que por mor da forte emigración, preferentemente cara á Arxentina, deixou de representarse. Así un dos informantes, que bailaba a danza cando era mozo, aló polos anos 50, presentoume a realidade así:

O meu mestre era o de todos, era Manuel da Cota e máis Ghalboio de Sorna. Despois marchou pa Buenos Aires e foi Manolo do Sexto no sitio e, despois, marchou Manolo do Sexto e foi o Farrapeiro a mais Manuel da Cota, despois... eu plantei de ir dansar.

Pero no ano 1979 outro grupo de mozos coa axuda dalgún maestro vello volveron a recuperala e, desde entón, séguese a representar cada ano, aínda que o número de danzantes sexa inferior, pois nunca se chegou aos 24 que seica era antes o habitual ou normal, e nos últimos anos por falta de mozos incluíron mozas.

Os danzantes, mozos da parroquia, vestidos de branco e cunha cinta azul cruzándolle o peito, agás os dous mestres que levarán pantalón de tergal e dúas cintas, e en número par, esperan a saída da procesión na porta da igrexa ${ }^{1}$. Cando esta vai saír erguen os arcos e pasan por debaixo deles

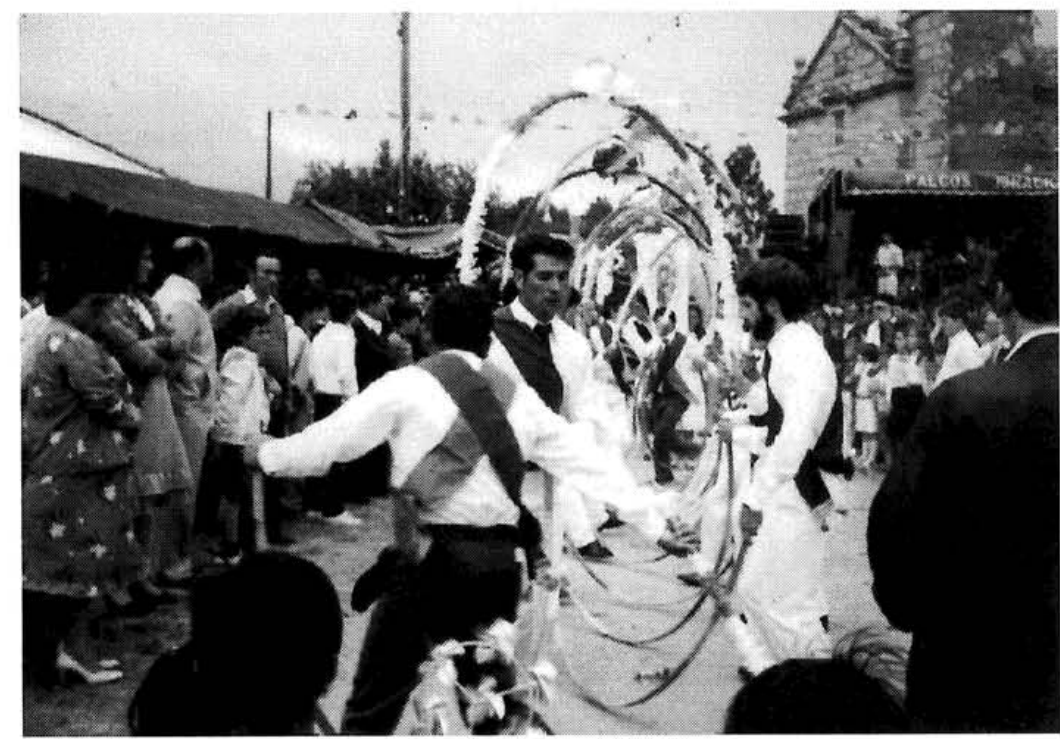

A danza dos arcos de Coucieiro a principios dos oitenta.

${ }^{1}$ Cóntanme que nalgunha ocasión tense entrado ao interior do templo.

"CUADERNOS DE ESTUdiOS GALLEGOS", Tomo XLII, Fascículo 107, Santiago 1995. 
as imaxes e os cregos. Unha vez que estes están no adro empeza a tocar a música $^{2}$ e empezan a danzar ao seu arredor facendo caracoles e culebras para logo saír cara ao campo en ringleira e volven facer arcos para rematar esta primeira parte saludando á Virxe cun xeonllo en terra. Esta sería a estructura da danza que sempre se repite as veces que queira o maestro. Pero o normal é que o faga ao chegar a procesión ao cruceiro e antes de entrar na igrexa. Os mestres levan unha vara na man para dirixir os danzantes, para dicirlles cando teñen que axeonllarse ou dar a volta, faino dando un golpe nun arco. Tamén utiliza a vara para apartar a xente e habíaos con fama de dar forte nas mozas e nas mulleres.

Despois a orquestra toca unhas pezas, que case ninguén baila, polo que a xente maior aproveita para dicir que "os mozos de aghora non saben bailar». Ao remate, ou xa antes, veciños e festeiros vanse a comer ás casas. Algúns veciños aproveitan este momento para convidar aínda aos festeiros que non puideron facelo antes. Pero «antes» tamén había xente de fóra da parroquia que traía a comida e comía polos arredores.

A xente da parroquia espera a festa do Socorro para lucir as roupas novas. E pola noite hai verbena con dúas orquestras e ten sona de ser unha das mellores «de toda esta volta» á que acoden mozos e mozas de varios concellos dos arredores.

\section{ROMARÍA DE SANTA MARIÑA}

Sta. Mariña é unha pequena aldea situada no extremo oeste da parroquia de tan só seis casas. Ten un santuario no que se venera a santa que dá nome ao lugar o 18 de xullo. Ao día seguinte celébrase o San Ramón, culto relativamente moi recente e que a penas ten incidencia na vida da aldea hoxe.

Non hai datos certos sobre a súa orixe, pero podemos supor que aínda non existía no ano 1606, pois cando o frade Gerónimo del Hoyo visitou esa comarca non a menciona, mais si cita outros santuarios próximos, como o de S. Roque en Moraime. Podemos supoñer que é anterior a 1676 pois nesta data empeza o libro da confraría. Tampouco sabemos cales son os motivos polos que se fundou. O anterior párroco, Manuel Canosa Mouzo,

\footnotetext{
${ }^{2}$ A música que tocan para a danza é unha «Muiñeira de Vimianzo». Debo este dato a Isidoro Rodríguez.
}

"CUADERNOS DE ESTUdiOS GALLEGOS", Tomo XLII, Fascículo 107, Santiago 1995. 
mantén a opinión de que a fundou unha familia importante do lugar, a de Juan de Agar que era capitán de Mar y Puerto en Muxía e que estaba casado con Aldoura Suárez, os cales logo se fixeron fidalgos en Corcubión ao redor do ano 1700. Nesta familia debía de haber un crego que estaría interesado en dicir misa no lugar, xa que Moraime quedáballe relativamente lonxe como para desprazarse até alí todos os días.

De feito o primitivo templo estaba pegado a esta casa, polo seu lado sur, até que no ano 1957 o cura e os veciños decidiron trasladalo a un campo, o Campo dos Castiñeiros, situado nos arrabales do lugar. O primitivo templo era relativamente moito máis pequeno co actual e estaba dividido en dous corpos. O presbiteiro era un cubo de tres metros por tres e a el accedíase despois de subir dúas escaleiras de cantería. De cantería tamén era o chan e a mesa do altar, o retablo era de madeira e nel estaba a primitiva imaxe, que foi roubada nos anos setenta, e outra máis recente e de tamaño maior que foi regalada polo cura sabio, don José Díaz Arosa, que fora natural da casa de Juan de Agar e era máis coñecido como menciñeiro. Un arco pequeno de cantería separada o presbiterio do corpo principal, este tiña uns oito metros de largo por uns seis de ancho e o chan era de cemento $^{3}$.

Esta pequena capela incrustada entre a casa do devandito señor de Agar e a doutro veciño, a de Vicente Abella, coñecida tamén polos apodos de $a$ casa da Paneira ou a casa do Romo, tiña un pequeno adro no que había uns carballos e unha mesa de pedra para pousar a carne de porco que ofrecían os devotos. No adro situábase a xente para escoitar a misa solemne que se dicía no interior do templo pero baixo a tribuna de madeira situada no corpo principal do mesmo. Este santuario pasou por varias vicisitudes, así en 1753 atopamos que «la capilla en que se halla colocada la santa se halla arruinada totalmente» polo que se tiveron que xuntar os veciños no Vao da Pedra «en junto al lugar que se llama de Cartel» no que se xuntaran para falar de amañar os camiños veciñais pero como alí tamén estaba presente o frade Nicolás Piñeiro, encargado da parroquia, e como moitos dos que alí estaban eran membros da confraría de Santa Mariña e vendo que esta «tiene cadual, de el se saquen hasta la cantidad de 160 reales» que levou en xornais Juan Antonio de Busto e Antonio Muiño, mestres de mampostería e carpintería. Xa neste século, concretamente no 1909, o párroco Ventura Mouzo tivo que reedificar a fachada.

\footnotetext{
${ }^{3}$ Debo estos datos a don Manuel Canosa Mouzo.
} 
Pensa don Manuel Canosa, que a devoción a Sta. Mariña foi introducida na comarca polos frades bieitos, que até 1833 tiveron convento en Moraime (neste convento estivo escondido de neno Alfonso VII durante as loitas entre os seus partidarios e os da súa nai dona Urraca), pois a súa xurisdición tamén pertencía outro santuario baixo a mesma advocación, no concello de Camariñas. Hai un terceiro santuario na comarca, en Paizás, no concello de Vimianzo, que en principio tamén entraría nos territorios dos monxes bieitos, pero deste sabemos que foi fundado por unha muller labrega rica a principios do s. XVII, chamada Mariña de Gondomil (Lema Suárez; 1993).

Como xa queda explicitado o lugar de Santa Mariña pertenceu á parroquia de Moraime ata o arranxo parroquial de 1868 polo que pasou a depender da de Coucieiro. Este feito quedou gravado na memoria popular como que Santa Mariña «escapou de Moraime polo que tiña as pisadas na Pedra Alta» As pegadas da Santa no monte que divide as dúas parroquias foron destruídas ao ensanchar un camiño. Desde que o lugar de Santa Mariña foi incorporado á parroquia de Coucieiro os de Moraime celebran, tamén, a súa Sta. Mariña, cousa que fan o 25 de xullo no santuario de San Roque.

A festa hoxe está en franca decadencia: «Foi unha festa moi importante astra a Gherra», dime unha muller de máis de 90 anos. A xente acode ao santuario desde parroquias doutros concellos próximos, como pode ser de Fisterra, Cée ou Dumbría, traendo unha ofrenda á santa, que ben pode ser froitos da terra (cada vez son menos, centeo e millo eran os máis importantes), pés de porco e rellos de atar as vacas. Estes dous últimos productos son os que teñen hoxe un maior peso e son subastados, a poxa, antes de empezar a misa solemne (até os anos 70 facíase despois da misa, pero o crego decidiu cambiar porque atrasaba moito a comida do medio día). Quizais o máis interesante da poxa sexa a dos rellos pois todos queren volver levar o rello que depositaron e se é vello din que é mellor cós novos, de aí que ás veces un rello que a penas vai valer para atar unha vaca pode triplicar o prezo do que pode custar novo.

Os devotos tamén levan a terra da santa, unha manchea de terra que agora teñen que cavala na porta da igrexa e que non fai moito o crego collía de calquera leira próxima na véspera, limpaba de pedras e raíces e, despois de bendicila, introducía nun espacio feito a propósito debaixo do altar maior. Este ritual de contacto activo coa terra con fins fecundadores ou protectores dáse en outros santuarios de Galiza, como por exemplo no de S. Alberte en Guitiriz (Blanco Prado; 1989).

"CUADERNOS DE ESTUdIOS GALLEGOS", Tomo XLII, Fascículo 107, Santiago 1995. 


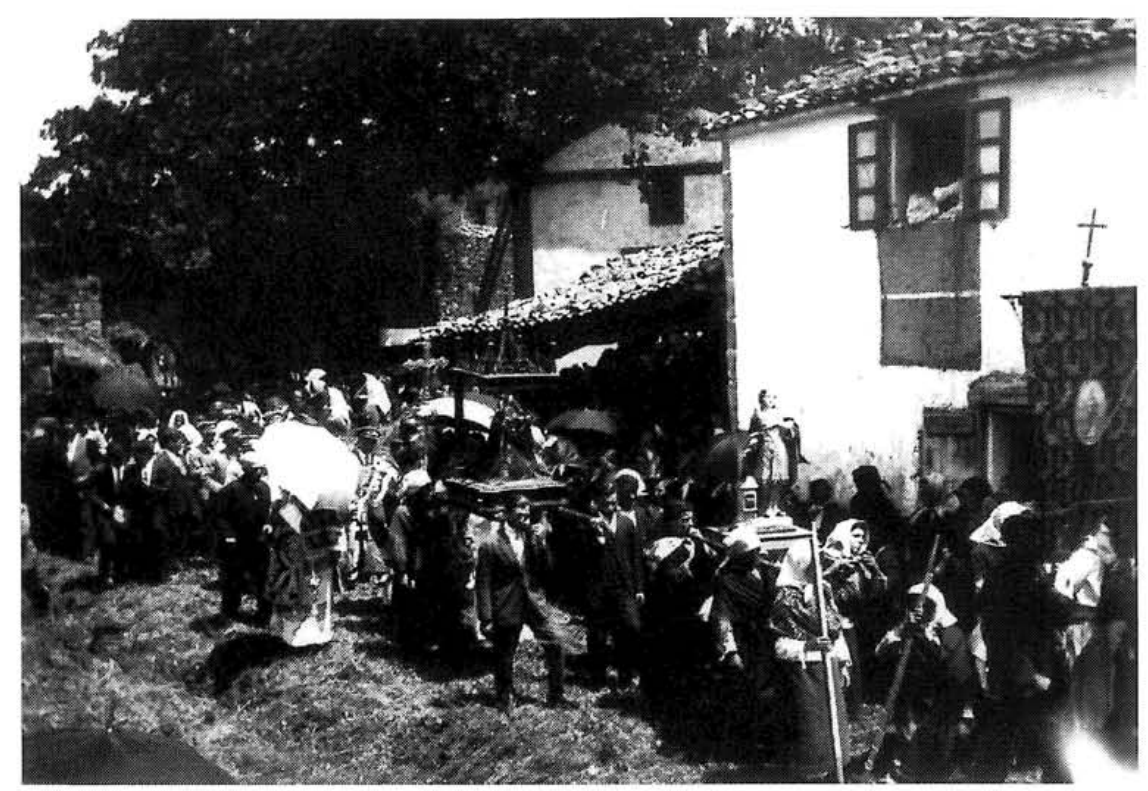

Procesión en Sta. Mariña, anos 40. Foto Ramón Caamaño.

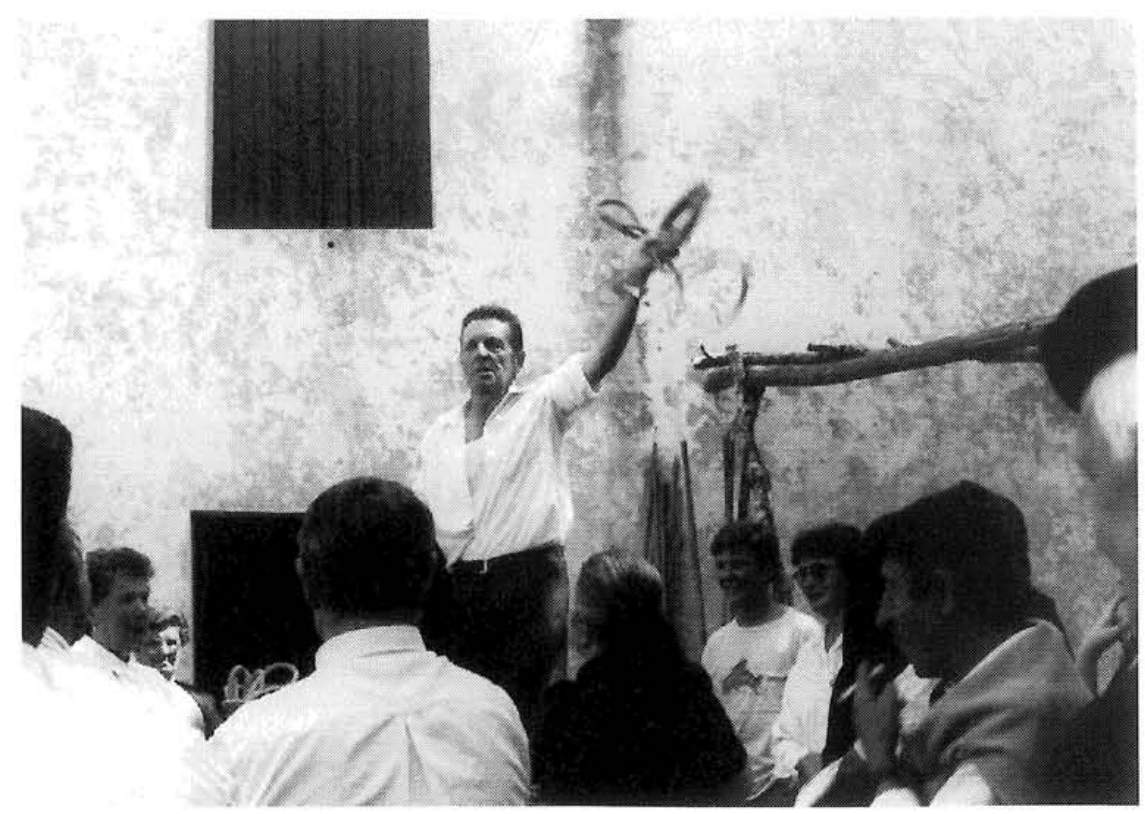

A poxa dos rellos na romaría de Sta. Mariña. 
Tamén se lle ten ofertado moita pólvora, tanta que «habia que abrilos parághuas para que non che caesen as canas». Era moi frecuente que os romeiros chegasen ao campo con unha ou dúas ducias de bombas debaixo do brazo que facían estalar para a Santa. Tamén se escoitaba nese día pólvora en toda a parroquia á que «contestaban os de Villastose e os de Añobres».

A santa Mariña a xente ofresialle pólvora e cartos e rellos, todo polos animales. Porque eu vin marchar sacos de terra cheos carghados nas éghuas pa botarlle ás vacas nunha bolsa colghada ó cuello pa que a vaca dese leite (tamén había quen lla mesturaba coa comida). Pa que empreñase botábanlle as bombas e mais para que non che morresen de disghraçia ou para que enfin, o rello ou a cadea de tela presa.

Outra informante tamén me relacionou o rito da terra coas colleitas: "cando o millo tiña bichoca disiamos "hai que ir buscar unha manchea de terra pa bichoca" $»$.

Despois dos actos relixiosos a xente sentaba á sombra dos poucos carballos, case que centenarios, para comer. Hoxe xa case ninguén o fai e a xente abandona o campo até a noite, para voltar á verbena, se é que a hai. Todos os actos corrían por conta do párroco: el dáballe de comer aos outros cregos e pagaba a música, até que a finais dos anos 70 e vendo que a festa ía desaparecer, os veciños xuntáronse e decidiron organizala eles. Pero despois duns anos de atraccións estelares, tipo Los dos Españoles ou Elsa Baeza, a festa esmorece e cando coincide coa festa parroquial de Moraime a penas xunta unha manchea de persoas.

A pesar desta coincidencia de datas ou de non ser xa festivo o día 18 , nunca escoitei a posibilidade de trasladala a outra data máis propicia, cousa que si parece frecuente en Andalucía ou, tamén, pasou aquí na veciña parroquia de Buiturón, que trasladaron para o domingo a festa de Espírito Santo.

Polos datos que tiramos dos arquivos sabemos que este era un dos poucos santuarios da comarca que tiña unha confraría e esta tiña o costume de facer entrega anualmente dun ramo ao maiordomo que exercía tal cargo durante o ano, así consta no libro que

dentro del priorato de San Julian de Moraime a 16 días del mes de agosto de 1755, delante del padre predicador, frai Nicolás Piñeiro, cura de esta feligresia, parecieron presentes José de Castiñeira y 
Salomé Conde, su muger, vecinos de esta feligresia... dixeron por don Anselmo Barrientos, presbitero; escusando a dicho Padre el día 18 del pasado se dió el Ramo de la cofradia al dicho José Castineiras lo que despues dicho padre-cura y algunos feligreses cofrades... repugnaban... que José Castiñeira era poco abonado para dar cuentas del caudal de la referida cofradía y pretendian volver a dar el ramo a otro $^{4}$.

\section{A SANTIÑA DE TRASUFRE}

Trasufre é outra aldea da parroquia de Coucieiro, duns trece veciños e situada no extremo este, unha vez pasado o río Castro, que cobre unha boa parte da fronteira entre o concello de Muxía e os de Dumbría e Cee. É dicir, Trasufre está xa no límite $\cos$ «da montaña», que non son coma nós. "Unha vez fun á festa ali [a montaña], a casa donde nasiu o home de miña tia L, que está en Venesuela, e de primeiro caldo, logho, callos, cosido, carne asada e veña todos a comer» contábame unha moza. Outro informante de máis de sesenta anos di que estes viñan nunhas «eghuiñas de dúas cuartas, cas alforxas arrastro». Todo un espectáculo e «si querías festa non tiñas máis que ir pa porta do Bollés». Ou atendamos ao refraneiro quen nos di que: "Os de Dumbría nin a agua fría» ou «de Dumbría nin egua nin cría». Son caracterizacións que implican unha moral despectiva e unha imaxe cultural do corpo (Velasco, 1981: 99).

O santuario da virxe de Aránzazu, chamada aquí do Espiño ou A Santiña, foi fundado por Francisco Bretal Mariño entre os anos 1785 e 1788, quen por aquel entón estaba de párroco en Coucieiro, para que durante o inverno puidesen acudir á misa os veciños de Trasufre xunto cos da Farrapa (caserío a medio $\mathrm{km}$. de Trasufre), e os de Calo, na veciña parroquia de Villastose, aproveitando a conxuntura de que na Farrapa había un crego. Bretal Mariño era dunha familia acomodada de Oleiros (Ribeira) e na súa casa tiñan unha capela adicada á Virxe de Aránzazu, da que hoxe non queda máis rastro que unha imaxe media abandonada na horta dun colexio privado. Debía ser moita a devoción que este crego tiña a tal Virxe porque, unha vez trasladado a outra parroquia na Estrada, santa Cristina de Vea, ergueu

\footnotetext{
${ }^{4}$ Libro de confraría, folio 135 volto. Copiado por don Manuel Canosa.
} 


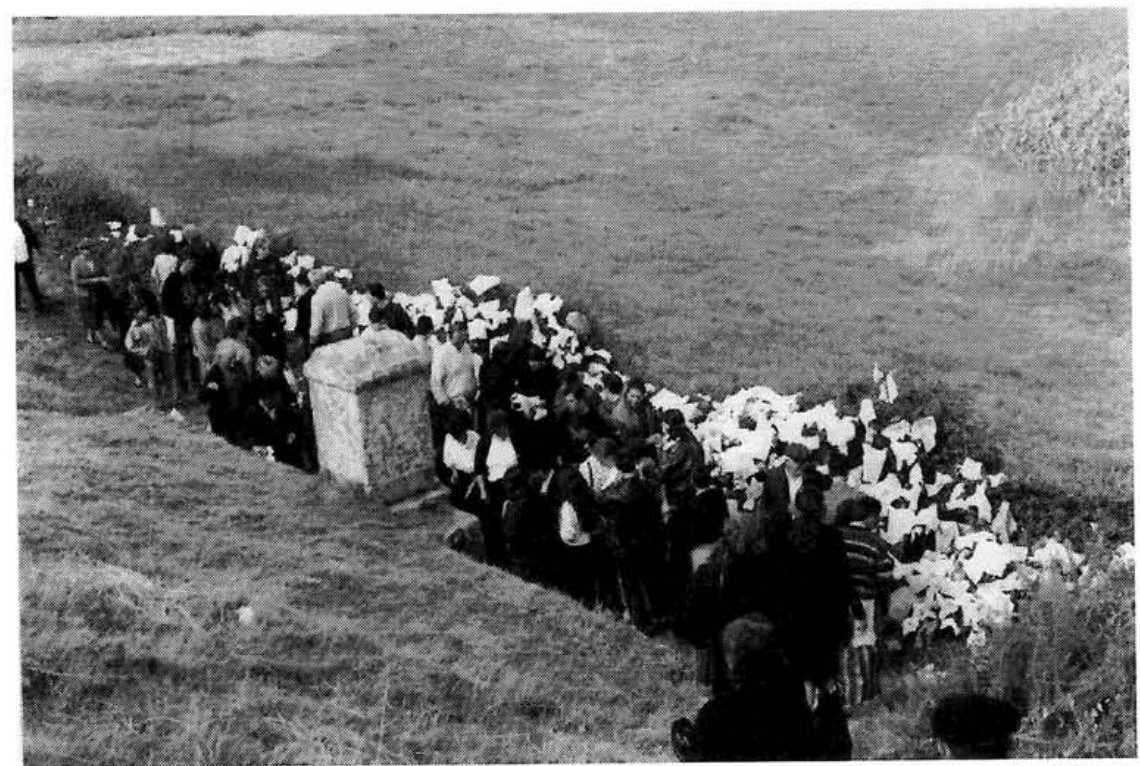

A fonte da Santa, en Trasufre, e os panos que os devotos van deixando pola silveira.

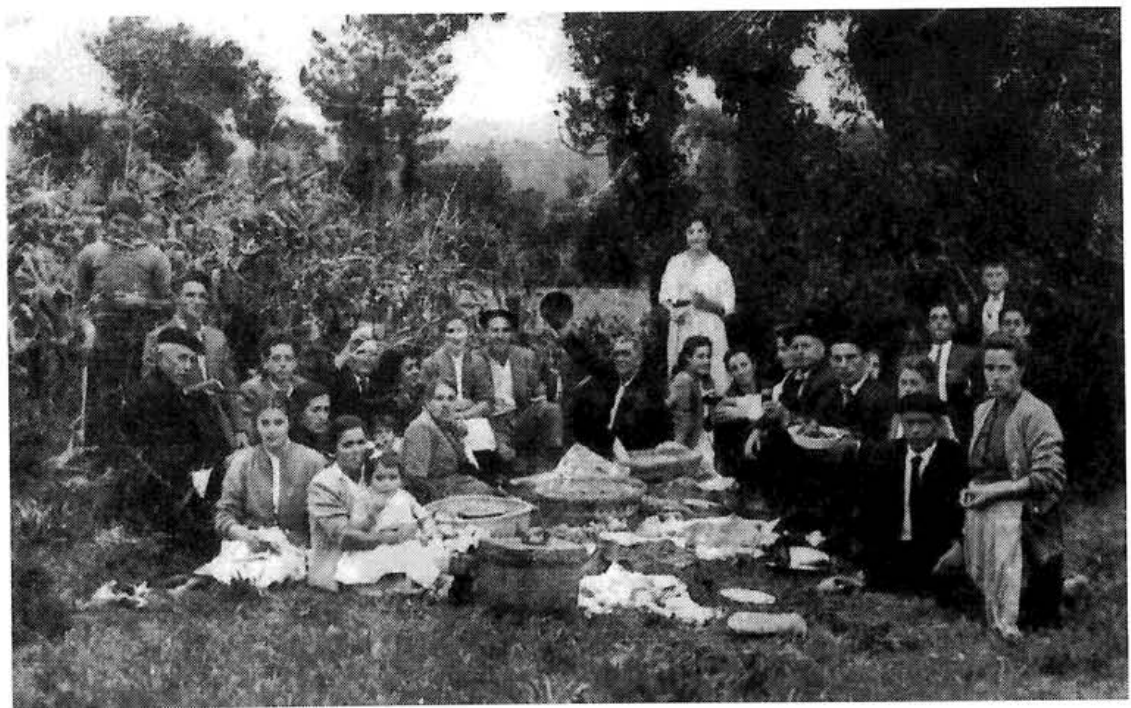

Comida familiar na romaría da Santiña de Trasufre. Foto González finais dos anos cincuenta. 
outro santuario que vinte anos despois xa estaba pechado. Posteriormente, entre 1878 e 1903, outro párroco ampliou o santuario, construíu a fonte para os peregrinos e ergueu a ponte sobre o río Castro.

No santuario da virxe da Eirita, xa en terra de Bergantiños, hai outra romaxe adicada a esta Virxe que fundou Francisco Vázquez Martínez, quen anteriormente estivera de párroco en Coucieiro, ao parecer levado polo enfado de que non o deixaran seguir como crego de Coucieiro.

O culto a esta Virxe, aparecida en Oñate nos albores da Idade Moderna, é realmente raro no noso país e céntrase na actualidade principalmente no santuario de Coucieiro e no da Eirita, sobrevivindo malamente en Vea. A miña hipótese sobre a orixe e difusión deste culto, totalmente guipuscoano, en Galiza pasa pola relación do santuario de Oñate coa orde franciscana, que estivo encargada do culto alí. Nun documento de doazón que Francisco Bretal Mariño e o seu cuñado Juan Antonio Sobrido fan no ano 1778 á ermida de Oleiros atopamos que

de $q^{e}$ el poseedor o poseedora $q^{e}$ fuese de estos otros vien" «a de tenerla precisa obliga ${ }^{\text {on }}$ de ospedar y mantener en su casa alos religiosos mendicantes del serafin Fran ${ }^{\text {co }}$ conv $^{\text {to }}$ de la Puebla» ${ }^{5}$.

A fabricación ou invención deste culto na parroquia de Coucieiro débese, como xa queda dito, á voluntade e intención de Francisco Bretal Mariño. A non moita documentación que atopamos fala sempre do mesmo: da necesidade dun templo para que os veciños puidesen asistir aos cultos durante o inverno porque o río Castro desbordaba e non podían acudir ás súas respectivas parroquias.

Contra a fabricación oficial atopamos a versión popular na que fan aparecer a Virxe en diferentes lugares próximos ao contexto ecolóxico do santuario:

A virghen da santa do Espiño aparisíu na pestanilla aquela que ten o puente de Trasufre ó lado de baixo, pa fóra, e pasabas por ali e si te arrodillabas choraba.

\footnotetext{
${ }^{5}$ Arquivo Diocesano de Santiago: mazo 385.
}

"CUADERnOS DE ESTUdios GALLEGOS", Tomo XLII, Fascículo 107, Santiago 1995. 
Outra versión leva esta aparición un pouco máis lonxe, a case un km. do santuario

A virghen aparesiu na fonte do Espiño, que está entre Aghar e Vilardouteiro.

Á santiña de Trasufre ofrécese a xente para que lle quite as verrugas e veñen desde toda a comarca, incluíndo a ribeira e a montaña; nos últimos anos chegaron dous autobuses con xentes dun punto tan distante como Baiona, xa no extremo sur do país. Unha informante de Toba, no concello de Cee, de 80 anos dícíame:

Eu a Santiña si que acordo siempre, día da Santiña ibanos desde aquí ca comida a comer á Santiña, que despois xa empesou a habe-los coches, e despois xa comíamos e íbanos despois de comer nos coches.

O ritual é o seguinte: os romeiros van chegando pola mañá para escoitar unha misa e deixar unha esmola ou un exvoto de cera. Se a ofrenda é en productos da terra, tales como millo, centeo ou trigo, deposítanse nunha casa que hai da parede do adro para fóra. Ao depositar as ofrendas reciben unha ou varias estampas coa imaxe da Virxe, que curiosamente non é igual cá que poden contemplar no altar, xa que esta está revestida cun manto branco e a da estampiña aparece encima do espiño e coa campaíña ${ }^{6}$. No interior do templo procuran acercarse á imaxe, pasarlle un pano e acenderlle unha vela. Logo desprázanse até a fonte onde lavaran as verrugas cun pano que despois deixarán a secar nas silveiras que bordean o camiño que pasa polo lado da fonte; din que mentres vai secando o pano tamén van secando as verrugas.

Despois ten lugar unha misa solemne e sae a procesión que percorre a aldea e baixo polo campo da festa, por unhas escaleiras de pedra que hai xunto ao palco da música, para volver entrar no adro. Ao remate a xente íase espallando polo monte e polos herbais para comer. Hai, ou había antes máis que agora, todo un ambiente de exhibición de comidas. As mulleres van estendendo o mantel, sobre o que ían colocando as viandas, ao redor

${ }^{6} \mathrm{O}$ feito de que a imaxe estivese vestida foi algo que non gustou a don Fermín Bouza Brey, que recomendou ao párroco que a desvestise (Bouza Brey: 1970, 260-1).

"CUADERNOS DE ESTUdIOS GALLEGOS", Tomo XLII, Fascículo 107, Santiago 1995. 
iranse sentando os comensais, xuntaranse varias xeracións e familiares que viven en diversas parroquias e, tamén, os de máis lonxe poden agruparse por aldeas. Aínda é moita a xente que vai comer á romaría da Santiña; é como unha obriga para todos os da parroquia e das máis próximas, tanto que «se o día da Santa se non iba comer ó campo pa min tanto tiña que fose Santa como que fose rañar a barrigha». Este ambiente festivo era propicio para os enfrentamentos entre mozos de diversas procedencias, era frecuente as pelexas «cos da montaña».

Á parte destas tres festas de sona, había outra que algúns informantes lembran como unha festa importante, a de San Miguel, á que acudía toda a parroquia coas merendas. Víñase celebrando na súa capela que estaba situada a uns 500 metros da igrexa parroquial no cimo dun outeiro (posiblemente un castro, pois «había mouros, pero eran os mismos cós do Castro, e baixaban a cabalo cara ó Vao do Lobo». Estes «mouros» pelexaban, tamén cos de Dumbría, concretamente cos que vivían nas Pedras Rubias). Desde a capela divisábase todos os lugares da parroquia que se asentan nas agras do val do río Castro, que son os máis populosos e os máis importantes, tanto polo seu peso económico como por seren os focos de atracción da vida social da parroquia. Aquí están os serradoiros, a escola (grupo escolar), o teléfono público, as tabernas e pasa o coche de liña. Antes vivía o practicante e había feira o segundo xoves de cada mes, que era o día no que o médico aproveitaba para dar consulta nunha concorrida taberna.

Mais o dato puramente etnográfico non coincide aquí coa documentación que achegan os textos históricos, nos que a capela de S. Miguel aparece sempre como moi abandonada. Así na visita pastoral de 1791 atopárona

profanada completamente y hecha establo de ganados mayores y menores con inmundicia de estos, sin puerta ni otra cosa más que indique ser tal capilla que una imagen de S. Miguel de piedra...

Pero isto non impedía que o día da festa do santo acudise á capela, segundo a mesma visita pastoral «un numeroso concurso de gente», o que nos indica que os parroquianos só ían ao monte de San Miguel de ano en ano, o día propio da festa e até a do ano seguinte non volvían. Estes mesmos datos documentais amosan unha certa deixadez e preguiza por parte das autoridades eclesiásticas á hora de atender os coidados da ermita, xa que está a menos de cincocentos metros da casa rectoral. 
$\mathrm{O}$ declive de $\mathrm{S}$. Miguel asóciano varios informantes ao párroco que se fixo cargo da parroquia no ano 1953. Así un dos informantes describe os últimos anos da festa:

A procesión íbamola a buscar a Cousieiro e iba pa riba. Despois habia misa e despois acabábase a misa e traíamola pa baixo e despois ibas a mirar as bailas arriba. Despois ó vir este [o crego] o primeiro ano xa botou as bailas da misa embaixo, pero o segundo ou o terceiro xa misou embaixo.

O culto a San Miguel viña apoiado por unha confraría desde 1711. No 1756 xa o cura a quixo xuntar coa das ánimas, pero non llo consentiron as autoridades eclesiásticas, cousa que si fixeron no 1766 (visita pastoral) permitindo que se agregase a do Rosario, porque aquela «se halla casi acabada... ya no se pagan caridades algunas y solo tiene seis ferrados de trigo anual». Así continuarona até 1863 «que quedaron en desuso por falta de caridades» e no 1871 uníronse á do Sacramento.

\section{FESTAS E IDENTIDADE}

Tense dito que «a festa expresa a identidade da comunidade que a celebra e reforza a súa unidade» (Pitt-Rivers; 1984, 22 e 21). A participación na festa expresa a adhesión a unha identidade colectiva. Esta pode ser local, parroquial e supralocal.

A festa patronal funciona como a ocasión precisa para rivalizar fronte aos grupos sociais limítrofes, e é sinónimo de prestixio e de lucimento, polo que todos os veciños da parroquia contribúen económicamente á organización das tres festas, incluídos os do anexo. Coa festa hai un reforzamento dos sentimentos de comunidade. A maior contribución fana para a festa parroquial, despois para a Santiña e, por último, para Sta. Mariña. Claro está que os dous últimos lugares dan máis para a súa festa que para as outras dúas e din que eles contribúen máis a festa parroquial que o resto da parroquia ás súas festas locais. Pero é que a festa parroquial é a única que ten un rival próximo e moi claro: a festa da parroquia veciña coa que ten que competir.

A pólvora avisa a parroquia do lado de que estamos en festa. A fin de semana seguinte eles van celebrar a súa festa parroquial, tamén o Socorro, "que é máis vello có noso». Por eses días un pode ir á taberna e entre os 
parroquianos o saúdo pode ser: "parese que non se escuita nada, $t i$ escuitastes algho», en clara referencia a que non se sente a pólvora en Villastose. «Será que este ano non teñen festa», contesta o outro, non sen certa dose de mordaz ironía.

A competitividade non só queda no enfrontamento dialéctico, «a nosa festa foi mellor cá vosa —dicíame un señor de Villastose-porque os coches cheghaban astra o Campo do Boi», é dicir, até cerca do límite da parroquia veciña, ou en cualificala sempre como máis aburrida. $O$ enfronta-mento vai máis alá, até tratar de impedir que os outros celebren a súa propia festa. Un informante relataba así estes propósitos:

Sempre viñan os de Villastose a quitarlle a lus, viña sempre ese condenado de Ramón do R. Pero os daqui tamén iban despois a quitarlla a Senande. Mira que iban a quitarlla a riba de Sibrán.

Acórdome que unha ves tocaba a orquesta "Sity», pois en toda a nuite non tocaria media dusia de pesas. Empesaba unha pesa e sás!, marchaba a lus, e alá iba Fidel a arreghlala ós Posos. Cheghaba Fidel ó campo e volvía a marchar, e así toda a noite.

A festa, como todos sabemos, ten un compoñente relixioso e outro lúdico. $\mathrm{O}$ da parroquia de Villastose pode ir a misa a un santuario de Coucieiro, pero non irá á misa do Socorro e viceversa. Participar do ritual doutra parroquia é participar da súa identidade, de colaborar a reforzar a identidade do «outro». Interrogando a un dos meus informantes sobre este tema, respondíame tallante: «eu sempre me levei ben con todos», pero pouco máis adiante dime que «nunca fun a misa ó Socorro de Villastose», para rematar dicindome que "fun unha ves, de rapás, que me deron un saqueto de roscas. Nun vulvinn,, di cortando bruscamente a conversa.

Un ano estando no campo da festa do Coucieiro o sábado pola tarde cando estaban ensaiando os danzantes e os membros da comisión distribuíndo as tabernas e colocando a iluminación, piden uns voluntarios para ir buscar un pau que había que colocar no medio do campo para termar do alumeado e das bandeiriñas. Un da comisión di que vaiamos buscalo a tal sitio (á leira dun veciño), pero os outros contestan que iso queda lonxe e que vai ser difícil traelo e propoñen ir buscalo a tras do monte de S. Miguel. Todos sabían que ese monte pertencía aos da parroquia de Villastose. Pero ao final decidiuse ir e cando chegaron ao campo co tronco de eucalipto todos empezaron a dicir: «e fóstello roubar os de 
Villastose». Se o tronco fose collido na leira dun da parroquia de Coucieiro non sería «roubado».

O mesmo podemos dicir dos que danzaban, «que eran todos da parroquia, nunca vén nincún do Anexo á danza, non carallo. Aghora si». Tamén si se precisaba algo, non se ía buscar á parroquia do lado. Por exemplo é normal que un mozo cando sabe que vai danzar non teña toda a roupa que precisa para ese momento e lla pida a algún amigo, pero nunca a un de fóra da parroquia.

Os danzantes van ser a imaxe que exportemos aos de fóra. Os danzantes son outro dos símbolos da parroquia, por iso se acicalan co mellor que tiñan para ese día:

Mira ho, eu o primeiro ano que fun dansar levei un reló de pulsera de des pesos que para máis non me daba o pelexo... que xa non tiña aghullas nin esfera... Despois xa estrenei un Sicart que custou 800 pesetas e comprouse pa quel día, e estreneino eu, que pa min nun fui, pero eu estreneino. Despois o terceiro ano xa comprei un reló por mil pesetas. A min tamén me ghustaba levar como os outros, o que non o tiña xa o roubaría. Sin reló nun iba nincún e sin o seu anillo de ouro tampouco.

ou este outro comentario:

o primeiro ano fun a Se e trouxen unha camisa que me custou trinta pesos e o pantalón corenta, unha camisa boa que na dansa daqueles anos non houbo outra coma ela. Tiña ghardadiña coma o millo da semente...

Pola contra as romarías da Santiña e de Santa Mariña aínda tendo un carácter local teñen unha repercusión supralocal. Son festas dunha aldea, pero tamén son festas doutra moita xente. Aquí hai varios niveis que debemos destacar. A festa é dos lugares nos que están situados os santuarios e a súa celebración é unha mostra de cohesión interna e de identidade local. Pero outras aldeas próximas participan e senten a romaría como a súa festa, aínda que pertenzan a outra parroquia. É o caso de Calo (Villastose) con Trasufre e de Prado (Morquintián) con Santa Mariña. Calo e Trasufre son os únicos dous lugares de Muxía que están na marxe esquerda do río Castro. Prado está illada do seu núcleo parroquial e compite no mesmo espacio xeográfico con Sta. Mariña, que tamén está illada do seu núcleo

"CUADERNOS DE ESTUdIOS GALLEGOS", Tomo XLII, Fascículo 107, Santiago 1995. 
parroquial. Ámbolos dous lugares, xunto con Agar, participan das súas festas parroquiais, como os demais membros da parroquia, pero tamén senten estas romarías como propias e ese día teñen festeiros coma o día da festa parroquial.

Os santuarios dan o toque plural a esta sociedade e este sentirse membros de dúas comunidades diferenciadas reflíctese no folclore

$$
\begin{aligned}
& \text { Cinta verde na mantilla } \\
& \text { parroquia de Coucieiro } \\
& \text { Santa Mariña que viva. }
\end{aligned}
$$

Pero este mesmo folclore nos fala das rivalidades, das diferentes identidades, entre os lugares próximos, pero membros de parroquias diferentes. Así en Sta. Mariña recollimos estos versos, probablemente fragmentos dunha regueifa:

$$
\begin{aligned}
& \text { O lugariño de Prado } \\
& \text { non é lugar nin alforxa } \\
& \text { ten unha corredoira vella } \\
& \text { onde o burro estrica a gorxa. }
\end{aligned}
$$

Distinguiría que os niveis de identidade que aquí reproducen estes rituais festivos son dous e están definidos pola territorialidade. Por un lado está o nivel parroquial: a parroquia é o centro do espacio sagrado da comunidade de fieis. Por outro lado, están as romarías que se sitúan na periferia desde territorio comunitario e que representan unha relixiosidade que escapa un pouco á xerarquía eclesiástica, con certos matices máxicos donde a terra e a auga, símbolos de fertilidade e purificación e imprescindibeis nunha sociedade agrícola, son elementos dominantes. Non só son estas manifestacións rituais periódicas relacionadas co ciclo da natureza e da producción agraria, senón que as relaciona simbolicamente.

Os santuarios son territorios precisos para a comunicación entre individuos de diversas parroquias e para a construcción dunha identidade supra parroquial sobre un referente sagrado compartido. En torno aos santuarios constrúese e definese unha identidade reducida ao espacio da aldea e, outra, máis ampla e relacionada cun espacio case comarcal.

$\mathrm{Na}$ festa parroquial os membros desa parroquia sentese iguais aos seus veciños pero diferentes aos veciños das outras parroquias. Pero esta identidade expresada na diferencia vencella a unhas parroquias coas outras 
e este interacción ritualízase e renóvase, entre outros, nas romarías. O feito de que periodicamente se celebra a festa xa implica un nivel de identificación colectiva.

Por outro lado temos que «as festas marcan o tempo... son ritos de paso» (Velasco; 1982, 172) polo que nunha sociedade até non hai moito eminentemente rural e labrega, estas festas tiñan que marcar o tránsito dunha etapa agrícola a outra. Deixando a un lado a festa parroquial, a de Sta. Mariña e a do Espiño tiñan que ver con diferentes ciclos productivos. A primeira celébrase en xullo, en tempo de sega e de sachar o millo e a isto fai referencia o refraneiro: «por Sta. Mariña apousa o sacho e colle a fouciña», é dicir, que os labores do millo xa teñen que estar rematados e debese encetar a sega; ou "por Sta. Mariña o millo xa cubre a galiña». A Santiña celébrase en setembro cando xa se rematou a colleita das fabas, que nesta zona significaban uns ingresos importantes, e está xa a punto a recolleita do millo. Algúns anos tense visto entre as ofertas a esta virxe espigas de millo novo que simbolizaban a próxima colleita.

Estamos de acordo co profesor Isidoro Moreno (1987), en que os iconos da Virxe ou da Santa Mariña, ao redor dos cales xira todo o ritual festivo, pasan de ser simplemente signos relixiosos a identificar grupos sociais situados nun determinado espacio ecolóxico?

\section{BIBLIOGRAFÍA}

BLANCO PRADO, J.M. 1989. Religiosidad Popular en el Municipio de Begonte. Santiago.

BOUZA BREY, Fermín. 1970. «El culto a Nuestra Señora de Aránzazu en Galicia». En Compostellanum, vol. XV, $\mathrm{n}^{\circ} 2$, Santiago.

GARCÍA GARCÍA, J.L.; VELASCO MAILLO, H. e outros. 1991. Rituales y Proceso Social. Estudio comparativo en cinco zonas de Espa$\tilde{n} a$. Ministerio de Cultura.

\footnotetext{
${ }^{7}$ Para a recollida do material etnográfico contamos cunha pequena axuda da Consellería de Cultura.
}

"CUADERNOS DE ESTUdIOS GALLEGOS", Tomo XLII, Fascículo 107, Santiago 1995. 
HOMOBONO, J.L. 1989. «Romería de San Urbano de Gaskue. Expresiones de religiosidad, sociabilidad y reproducción de identidades colectivas». Cuadernos de Etnología y Etnografia de Navarra. $\mathrm{N}^{\circ} 54$.

LEMA SUÁREZ, X.Mª 1993. A Arte Relixiosa na Terra de Soneira. Coordenadas, Santiago.

MORENO, Isidoro. 1987. «Niveles de significación de los iconos religiosos y rituales de reproducción de identidad de Andalucía». En: La Fiesta, la Ceremonia, el Rito. Granada.

PITT-RIVERS, J. 1982. «La identidad local a traés de la fiesta». Revista de Occidente, $\mathrm{n}^{\circ}$ 38-39, Madirid.

TORRES LUNA, Ma P. e outros. 1989. Municipios y Parroquias de Galicia. Universidade de Santiago de Compostela.

VELASCO MAHILLO, H. 1982. «Fiestas de Mayo en la Tierra de Alcalá». En: Tiempo de Fiesta. Ensayos antropológicos sobre la fiesta en España. Tres-Catorce-Diecisiete. Madrid.

VELASCO MAHILLO, H. 1981. «Textos sociocéntricos. Los mensajes de identificación y diferenciación entre comunidades rurales». En:Revista de Dialectologia y Tradiciones Populares.t. XXXVI, Madrid. 